\title{
Childhood bruising distribution observed from eight mechanisms of unintentional injury
}

Owen Hibberd, Diane Nuttall, Rhiannon E Watson, William J Watkins, Alison Mary Kemp, Sabine Maguire

\section{ABSTRACT}

Objective To inform the assessment of described mechanisms of bruising in children.

Design Prospective cross-sectional study.

Setting The emergency department, and children in the local community.

Patients Children aged 0-13 years with bruises from unintentional injuries. Exclusions: bleeding disorder, medication affecting coagulation or child protection concerns.

Interventions Injury incidents were categorised into one of eight causal mechanisms (fall from $<1 \mathrm{~m}$, 1-2 $\mathrm{m}$, fall from standing height or less and hitting an object during fall, stairs or impact, crush, sports or motor vehicle collision).

Main outcome measures Location, number and mechanism of bruising for each injury mechanism.

Results 372 children had 559 injury incidents, resulting in 693 bruises; 85.2\% of children were walking independently, with impact injuries and fall from standing height (including hitting an object) being the predominant mechanisms. A single bruise was observed in $81.7 \%$ of all incidents. Stair falls resulted in $\geq 3$ bruises only with falls involving $\geq 10$ steps $(6 / 16)$. Bruising was rarely observed on the buttocks, upper arm, back of legs or feet. No bruises were seen in this dataset on ears, neck or genitalia. Petechial bruising was only noted in 1/293 unintentional incidents, involving a high-impact injury in a school-aged child.

Conclusion These findings have the potential to aid an assessment of the plausibility of the explanation given for a child with bruising. Certain bruise distributions were rarely observed, namely multiple bruises from a single mechanism, petechial and bruising to the ears, neck or genitalia.

\section{What is already known?}

Unintentional bruises occur predominantly over anterior bony prominences such as the elbows, shins, knees and in a T-shaped distribution across the face.

The prevalence and number of bruises that a child has at any one time increases with greater independent mobility.

Individual mechanisms of injury have been explored, but have rarely differentiated bruising from other soft tissue injuries.

\section{What this study adds?}

A description of bruising distribution relative to the mechanism of injury among a large population of young children with unintentional injuries. 
Among 559 injuries from falls, impact, crush, sports and motor vehicle collision (MVC), 81.7\% resulted in single bruises; exceptions being falls 1-2 $\mathrm{m}$, stair falls, sports and MVC.

Regardless of the mechanism, no bruises to the ear, neck or genitalia were observed, with petechial bruising being rare.

\section{INTRODUCTION}

\section{Background}

Distinguishing bruises that children sustain from unintentional injuries, from those due to abuse, is challenging. Bruises may be the sole presenting feature of physical abuse. The assessment rests on an evaluation of the plausibility of the explanation offered for the injuries seen, largely based on experience. A clinician needs an understanding of the mechanisms involved in unintentional injury, and the distribution of bruises that ensues, to inform their decisions as to the relative likelihood of those mechanisms.

Recent studies have focused on the distribution of bruises in physical abuse or unintentional injury. Some explored injuries resulting from specific mechanisms but often combining all soft tissue injuries. Biomechanical models to determine impact sites have also been explored, while some studies were restricted by body part (eg, ear injuries) or single mechanisms, for example, motor vehicles collisions (MVC).

This study aims to describe the distribution of bruises from a spectrum of unintentional injury mechanisms in children aged $<13$ years, to inform an evidence-based assessment of bruises.

\section{METHODS}

\section{Ascertainment}

This prospective cross-sectional study was conducted in two settings: the emergency department (ED) of the University Hospital of Wales, Cardiff (ED cohort), and children in the community whose injuries were not medically attended (community cohort)13 (see online supplementary appendix 1). Parents of children $<13$ years old were approached if the child had a bruise of known origin (child $\geq 4$ years old/caregiver could describe the incident which resulted in the bruise/s), whether or not it was the reason for attendance at the ED.

For the community cohort, flyers were distributed to playgroups, and primary and secondary care clinics to invite parents of children aged $<6$ years to participate in a longitudinal study of bruising patterns from 2005 to 2011 (details in Kemp et al 2015).13 An amendment to the ethical approval of this study allowed collection of data on the cause of injury where known for phase 213(2008-2011). A cross section of data on children in this study, 13 who had a bruise of known origin, was extracted for further analysis. These children did not sustain any serious injuries, and thus did not require medical attendance.

We excluded children with a known bleeding disorder, medication that might impair coagulation, pre-existing disability, any child protection concerns or unwitnessed injuries in children $<4$ years of age. All children $<1$ year of age in the ED underwent a safeguarding evaluation by a consultant paediatrician. 


\section{Data collection}

Demographic data including age, gender and developmental stage were recorded. Details of the injury incident (a single injury that resulted in bruising) were obtained from the parent, and child (when possible). Injuries were categorised into one of eight commonly seen mechanisms (adapted from the International Classification of External Causes of Injury).

The location and number of bruises per incident were recorded on body charts. In the ED, bruises were examined and recorded by the researchers. In the community cohort, parents were trained to record site and cause of bruising on their child, which they did weekly for up to 12 weeks, with a random sample of 40 data collections from 40 different children independently verified by the research nurse to validate the quality and consistency of recording.13 The presence of petechiae was recorded for the ED cohort only, as this was considered difficult for parents to identify.

\section{Statistical methods}

Statistical analysis was conducted using $\chi 2$ tests for overall comparisons, with significance set at $\mathrm{p}<0.05$. In addition, we explored the feasibility of a predictive model to determine the relative probabilities of a pattern of bruising given different mechanisms through a multinomial logistic regression model, conducted using the mlogit package in $\mathrm{R}$, with the mechanism of bruising as the outcome variable. For the attempted logistic regression, bruising locations were reduced to 16 sites due to low numbers. Data were split into data used to form the model, and data used to test the model. Each child was only used once in the logistic regression, removing the need for a hierarchical structure to deal with more than one mechanism/bruise set per child. However, when a child had bruises resulting from more than one incident, these data were used in the summary statistics.

\section{Ethical approval}

Following provision of information sheets, written informed consent was obtained. Ethical approval was granted (Reference 05/MRE11/8 \& 09/H0504/53), with an extension for ED data collection (Reference 09/RPM/4510).

\section{Results}

Of 606 injury incidents of known origin, 47 (41 community) were excluded due to insufficient information to classify the mechanism, unwitnessed injury in a child $<4$ years, or not being one of the eight predefined mechanisms14 (eg, a dog bite). This left 559 incidents of bruising among 372 children (male 51.3\%); 293 incidents recorded in ED and 266 in the community; 106 children (40 ED, 66 community) provided information about a number of bruises from multiple separate incidents of injury.

The majority of participants in our study were Caucasian (526/559: 94.1\%), consistent with the regional demographics, where $95.9 \%$ of the population in Wales are Caucasian.15 As only 146/293 (49.8\%) incidents of injury ascertained from the ED, involved bruises related to the child's ED presentation, 414/559 (74.1\%) of incidents in total were equivalent to non-medically attended injuries. Among the ED cohort, 132/293 (45.1\%) of patients were recruited within 6 hours of their injury.

The most common cause of bruises were falls from $<1 \mathrm{~m}$, closely followed by impact injuries. No falls from over $2 \mathrm{~m}$ were seen, and therefore this was not included as one of the categories of injury 
mechanisms. Sports injuries predominated among older children attending the ED. The mechanism of bruising was significantly ( $p<0.001$ ) different between boys and girls, primarily due to sports injury. With the exception of sports related bruising, there was no overall gender difference $(p=0.29)$.

The majority of bruises $476 / 559$ (85.2\%) occurred in children who were walking independently (table 1). Only seven incidents involved a non-mobile baby, not yet sitting. Two involved a fall from 1 to 2 $\mathrm{m}$ : one when the shopping trolley he was sitting in was pulled over by a sibling and the other involved a baby sleeping on a father's chest while sitting on a sofa, he fell asleep and dropped the baby onto the floor. One mother slipped while going downstairs dropping the baby (stair fall). Four children experienced impact injuries: two babies had objects dropped onto them, keys and a toy respectively, one baby was bumped with a rattle and another was accidentally hit by a belt buckle when a sibling was swinging a belt around. All of the above incidents were deemed unintentional injuries following appropriate assessment by a paediatrician.

Table 1 Demographic data from 559 incidents of injury resulting in bruises among 372 children aged $<13$ years

\begin{tabular}{|c|c|c|c|c|c|c|c|c|c|c|}
\hline & & $\begin{array}{c}\text { Total } \\
\text { number } \\
\text { of } \\
\text { incident } \\
s\end{array}$ & $\begin{array}{c}\text { Fall } \\
\text { from }<1 \\
m\end{array}$ & $\begin{array}{l}\text { Fall from } \\
\text { standing } \\
\text { height or } \\
\text { less and } \\
\text { hitting } \\
\text { an object } \\
\text { during } \\
\text { fall }\end{array}$ & $\begin{array}{c}\text { Fall } \\
\text { from } 1 \\
\text { to } 2 \mathrm{~m}\end{array}$ & $\begin{array}{c}\text { Stair } \\
\text { fall }\end{array}$ & $\begin{array}{l}\text { Impact } \\
\text { injury }\end{array}$ & $\begin{array}{l}\text { Sports } \\
\text { injury }\end{array}$ & $\begin{array}{c}\text { Motor } \\
\text { vehicle } \\
\text { collisio } \\
\mathbf{n}\end{array}$ & $\begin{array}{l}\text { Crush } \\
\text { injury }\end{array}$ \\
\hline $\begin{array}{l}\text { Number of } \\
\text { incidents of } \\
\text { injury }\end{array}$ & $\begin{array}{l}\text { ED cohort } \\
\text { Community } \\
\text { cohort }\end{array}$ & $\begin{array}{l}293 \\
(100 \%) \\
266 \\
(100 \%)\end{array}$ & $\begin{array}{l}100 \\
(34.1 \%) \\
98 \\
(36.8 \%)\end{array}$ & $\begin{array}{l}34 \\
(11.6 \%) \\
62 \\
(23.3 \%)\end{array}$ & $\begin{array}{l}21 \\
(7.2 \%) \\
3 \\
(1.1 \%)\end{array}$ & $\begin{array}{l}17 \\
(5.8 \%) \\
8 \\
(3.0 \%)\end{array}$ & $\begin{array}{l}56 \\
(19.1 \%) \\
86 \\
(32.3 \%)\end{array}$ & $\begin{array}{l}51 \\
(17.4 \%) \\
7(2.7 \%)\end{array}$ & $\begin{array}{l}7(2.4 \%) \\
0(0.0 \%)\end{array}$ & $\begin{array}{l}7 \\
(2.4 \%) \\
2 \\
(0.8 \%)\end{array}$ \\
\hline $\begin{array}{l}\text { Median age } \\
\text { in months at } \\
\text { time of } \\
\text { incident } \\
(I Q R)^{*}\end{array}$ & $\begin{array}{l}\text { ED cohort } \\
\text { Community } \\
\text { cohort }\end{array}$ & $\begin{array}{l}60(26- \\
102) \\
23(14- \\
40)\end{array}$ & $\begin{array}{l}60(36- \\
84) \\
28.5 \\
(15- \\
40.75)\end{array}$ & $\begin{array}{l}36 \\
\left(31.75^{-}\right. \\
60) \\
16.5(12- \\
30)\end{array}$ & $\begin{array}{l}36 \\
(20- \\
60) \\
46 \\
(41- \\
47)\end{array}$ & $\begin{array}{l}22(15- \\
72) \\
47 \\
(35.25 \\
- \\
51.25)\end{array}$ & $\begin{array}{l}85.5(36- \\
120) \\
22(12- \\
37.5)\end{array}$ & $\begin{array}{l}106 \\
\left(78.5^{-}\right. \\
120) \\
40\left(31.5^{-}\right. \\
41)\end{array}$ & $\begin{array}{l}72 \\
\left(26.5^{-}\right. \\
96) \\
\text { N/A }\end{array}$ & $\begin{array}{l}36 \\
(32.5- \\
78) \\
46.5 \\
(34.75 \\
- \\
58.25)\end{array}$ \\
\hline $\begin{array}{l}\text { Gender at } \\
\text { time of } \\
\text { incident }\end{array}$ & $\begin{array}{l}\text { Male } \\
\text { Female }\end{array}$ & $\begin{array}{l}287 \\
(51.3 \%) \\
272 \\
(48.7 \%)\end{array}$ & $\begin{array}{l}88 \\
(15.7 \% \\
110 \\
(19.7 \%)\end{array}$ & $\begin{array}{l}51(9.1 \%) \\
45(8.0 \%)\end{array}$ & $\begin{array}{l}10 \\
(1.8 \%) \\
14 \\
(2.5 \%)\end{array}$ & $\begin{array}{l}10 \\
(1.8 \%) \\
15 \\
(2.7 \%)\end{array}$ & $\begin{array}{l}71 \\
(12.7 \%) \\
71 \\
(12.7 \%)\end{array}$ & $\begin{array}{l}47 \\
(8.4 \%) \\
11 \\
(2.0 \%)\end{array}$ & $\begin{array}{l}6(1.1 \%) \\
1(0.2 \%)\end{array}$ & $\begin{array}{l}4 \\
(0.7 \%) \\
5 \\
(0.9 \%)\end{array}$ \\
\hline $\begin{array}{l}\text { Development } \\
\text { al stage at } \\
\text { time of } \\
\text { incident }\end{array}$ & $\begin{array}{l}\text { Non-mobile } \\
\text { baby }{ }^{+} \\
\text {Not yet sitting } \\
\text { Sitting } \\
\text { Crawling } \\
\text { Cruising } \\
\text { Walking }\end{array}$ & $\begin{array}{l}7 \\
6 \\
22 \\
48 \\
476\end{array}$ & $\begin{array}{l}0 \\
1 \\
5 \\
12 \\
180\end{array}$ & $\begin{array}{l}0 \\
1 \\
6 \\
15 \\
74\end{array}$ & $\begin{array}{l}2 \\
0 \\
0 \\
1 \\
21\end{array}$ & $\begin{array}{l}1 \\
1 \\
0 \\
1 \\
22\end{array}$ & $\begin{array}{l}4 \\
3 \\
11 \\
19 \\
105\end{array}$ & $\begin{array}{l}0 \\
0 \\
0 \\
0 \\
58\end{array}$ & $\begin{array}{l}0 \\
0 \\
0 \\
0 \\
7\end{array}$ & $\begin{array}{l}0 \\
0 \\
0 \\
0 \\
9\end{array}$ \\
\hline
\end{tabular}

\footnotetext{
*The difference in age between cohorts reflects the difference in cohorts, namely the community cohort were aged 0-6 years.

$\uparrow$ Non-mobile baby = non-mobile, not yet sitting. Sitting = sitting, not yet mobile.

IQR, Inter Quartile Range; ED, emergency department.
} 
A total of 693 bruises were recorded from 559 incidents, details of bruise locations by mechanism of injury are in table 2 . The forehead and shins were the most frequently bruised sites.

No bruising was observed on the ears, neck or genitalia in any child. Bruising to the front of the trunk, upper arms, hands, lips, buttocks and back of the legs, each represented $<3 \%$ of the 693 bruises. Bruises to the cheeks were seen in 33/693 (4.8\%) incidents; however, data collection did not differentiate between bruising over the zygomatic bone and the soft aspect of the cheek. Only one incident of bruising to the abdomen was recorded, an impact injury in a 7-year old who ran into the corner of a metal bench. The mechanism most commonly resulting in bruises to posterior surfaces of the body, for example, back, buttocks and the back of the thighs, were children falling from standing height or less and hitting an object during their fall 18/35 (51\%). 
Table 2 The body locations (23) and \% per mechanism of injury, for bruises noted among 559 incidents where a bruise resulted from a known unintentional injury in children aged $<13$ years

\begin{tabular}{|c|c|c|c|c|c|c|c|c|c|}
\hline Bruise location & $\begin{array}{l}\text { All mechanisms } \\
\text { combined } \\
n=559 \text { number } \\
\text { of bruises in } \\
\text { this location } \\
\text { (\% of total } \\
\text { bruises) }\end{array}$ & $\begin{array}{l}\text { Fall from }<1 \mathrm{~m} \\
\mathrm{n}=198 \\
\text { (\% of total bruises/ } \\
\text { mechanism) }\end{array}$ & $\begin{array}{l}\text { Fall from standing } \\
\text { height or less and } \\
\text { hitting an object } \\
\text { during fall } n=96 \text { (\% } \\
\text { of total bruises/ } \\
\text { mechanism) }\end{array}$ & $\begin{array}{l}\text { Fall from } 1 \text { to } \\
2 \mathrm{~m} \\
\mathrm{n}=24 \text { (\% of } \\
\text { total } \\
\text { bruises/mecha } \\
\quad \text { nism) }\end{array}$ & $\begin{array}{l}\text { Stair fall } \\
\mathrm{n}=25(\% \\
\text { of total } \\
\text { bruises/ } \\
\text { mechanism) }\end{array}$ & $\begin{array}{l}\text { Impact } \\
\text { injury } \\
\mathrm{n=142} \\
\text { (\% of } \\
\text { total } \\
\text { bruises/ } \\
\text { mechani } \\
\quad \mathrm{sm}) \\
\end{array}$ & $\begin{array}{l}\text { Sports } \\
\text { injury } n=58 \\
\text { (\% } \\
\text { of total } \\
\text { bruises/ } \\
\text { mechanism) }\end{array}$ & $\begin{array}{l}\text { Motor } \\
\text { vehicle } \\
\text { collision } n=7 \\
\text { \% of total } \\
\text { bruises/ } \\
\text { mechanism }\end{array}$ & $\begin{array}{l}\text { Crush } \\
\text { injury } \\
\mathrm{n}=9 \text { (\% of } \\
\text { total } \\
\text { bruises } / \mathrm{m} \\
\text { echanism) }\end{array}$ \\
\hline Head & $32(4.6)$ & 9 (3.9) & $5(4.3)$ & $3(9.1)$ & $3(7.3)$ & $11(7.4)$ & $1(1.1)$ & $0(0)$ & $0(0)$ \\
\hline Forehead & $154(22.2)$ & $45(19.6)$ & $37(32.2)$ & $8(24.3)$ & $12(29.4)$ & $44(29.7)$ & $5(5.3)$ & $3(15)$ & $0(0)$ \\
\hline Nose & $23(3.3)$ & $6(2.6)$ & $3(2.6)$ & $1(3)$ & $6(14.6)$ & $3(2)$ & $1(1.1)$ & $3(15)$ & $0(0)$ \\
\hline Eyes & $16(2.3)$ & $1(0.4)$ & $6(5.2)$ & $0(0)$ & $0(0)$ & $6(4)$ & $1(1.1)$ & $2(10)$ & $0(0)$ \\
\hline Cheeks & $33(4.8)$ & $5(2.2)$ & $11(9.6)$ & $0(0)$ & $2(4.9)$ & $10(6.8)$ & $2(2.1)$ & $3(15)$ & $0(0)$ \\
\hline Lips & $7(1)$ & $3(1.3)$ & $2(1.7)$ & $0(0)$ & $0(0)$ & $1(0.7)$ & $0(0)$ & $1(5)$ & $0(0)$ \\
\hline Chin & $15(2.2)$ & $4(1.7)$ & $4(3.5)$ & $1(3)$ & $2(4.9)$ & $2(1.4)$ & $2(2.1)$ & $0(0)$ & $0(0)$ \\
\hline Ears & $0(0)$ & $0(0)$ & $0(0)$ & $0(0)$ & $0(0)$ & $0(0)$ & $0(0)$ & $0(0)$ & $0(0)$ \\
\hline Neck & $0(0)$ & $0(0)$ & $0(0)$ & $0(0)$ & $0(0)$ & $0(0)$ & $0(0)$ & $0(0)$ & $0(0)$ \\
\hline Trunk - front & $14(2)$ & $4(1.7)$ & $0(0)$ & $4(12.1)$ & $0(0)$ & $1(0.7)$ & $3(3.2)$ & $2(10)$ & $0(0)$ \\
\hline Trunk - back & $23(3.3)$ & $3(1.3)$ & $10(8.7)$ & $1(3)$ & $3(7.3)$ & $4(2.7)$ & $1(1.1)$ & 1 (5) & $0(0)$ \\
\hline Upper arms & $7(1)$ & $1(0.5)$ & $0(0)$ & $0(0)$ & $1(2.4)$ & $2(1.4)$ & $2(2.1)$ & $1(5)$ & $0(0)$ \\
\hline Elbow & $22(3.2)$ & $15(6.5)$ & $0(0)$ & $1(3)$ & $1(2.4)$ & $2(1.4)$ & $3(3.2)$ & $0(0)$ & $0(0)$ \\
\hline Lower arms & $15(2.2)$ & $6(2.6)$ & $1(0.9)$ & $4(12.1)$ & $1(2.4)$ & $2(1.4)$ & $1(1.1)$ & $0(0)$ & $0(0)$ \\
\hline Hand & $17(2.5)$ & $4(1.7)$ & $0(0)$ & $0(0)$ & $0(0)$ & $6(4)$ & $2(2.1)$ & $0(0)$ & $5(41.7)$ \\
\hline Buttocks & $4(0.6)$ & $0(0)$ & $3(2.6)$ & $0(0)$ & $0(0)$ & $1(0.7)$ & $0(0)$ & $0(0)$ & $0(0)$ \\
\hline Genitalia & $0(0)$ & $0(0)$ & $0(0)$ & $0(0)$ & $0(0)$ & $0(0)$ & $0(0)$ & $0(0)$ & \\
\hline Front of thighs & $28(4.1)$ & $13(5.7)$ & $3(2.6)$ & $0(0)$ & $3(7.3)$ & $6(4)$ & $2(2.1)$ & $1(5)$ & $0(0)$ \\
\hline Back of thighs & $5(0.7)$ & $0(0)$ & $5(4.3)$ & $0(0)$ & $0(0)$ & $0(0)$ & $0(0)$ & $0(0)$ & $0(0)$ \\
\hline Knee & $64(9.2)$ & $32(13.9)$ & $3(2.6)$ & $2(6.1)$ & $1(2.4)$ & $5(3.4)$ & $18(19.2)$ & $1(5)$ & $2(16.7)$ \\
\hline Below knee - front & $190(27.4)$ & 77 (33.5) & $21(18.3)$ & $5(15.2)$ & $5(12.3)$ & $31(20.9)$ & $48(51.1)$ & $2(10)$ & $1(8.3)$ \\
\hline Below knee - back & $3(0.4)$ & $0(0)$ & $0(0)$ & $0(0)$ & $0(0)$ & $0(0)$ & $2(2.1)$ & $0(0)$ & $1(8.3)$ \\
\hline Foot & $21(3)$ & $2(0.9)$ & $1(0.9)$ & $3(9.1)$ & $1(2.4)$ & $11(7.4)$ & $0(0)$ & $0(0)$ & $3(25)$ \\
\hline Total number of bruises & $693(100)$ & $230(100)$ & $115(100)$ & $33(100)$ & $41(100)$ & $\begin{array}{l}148 \\
(100)\end{array}$ & $94(100)$ & $20(100)$ & $12(100)$ \\
\hline
\end{tabular}

*In this context, 'head' refers to the area within the hairline. 
The number of bruises arising from different mechanisms is shown in table 3. Of the 559 incidents, $457 / 559$ (81.7\%) resulted in a single bruise, $77 / 559$ (13.8\%) had two bruises and 25/559 (4.5\%) had three or more. Four bruises were observed in 3/559

(0.5\%) incidents (one stair fall, two sports injuries) and 2/559 (0.4\%) involved in MVCs sustained five bruises, all of these children were independently mobile. No more than five bruises were seen from a single incident. Of the remainder who had three bruises 20/559 (3.6\%), these were predominantly caused by stair falls and sports injuries.

When more than one bruise resulted from a single incident, the bruises were on the same body location, adjacent limbs and/ or over a bony surface such as elbows, knees or facial $\mathrm{T}$ (ie, forehead, nose, lips and chin). Bruising to the front and back of the body from a single injury incident was seen only twice: once where a child fell down a flight of 12 steps, and a pedestrian hit by a car travelling at 20-25 mph.

The number of steps fallen among stair falls was recorded in 16/25 (64\%); 10 fell down fewer than 10 steps, none had $>2$ bruises. All six incidents involving $10-14$ steps resulted in $\geq 3$ bruises, involving various body locations.

Sports injuries were associated with $\geq 3$ bruises in 7/58 (12\%) of incidents. Bruising sites were consistent across different sporting activities.

There were 142 impact injuries: 96 involved moving children colliding with a stationary object (eg, ran into a wall) and 46 involved a moving object, for example, a ball. Whether the child was hit by, or hit, an object did not influence the site of bruising, and only $6 / 142$ (4.2\%) incurred $\geq 2$ bruises. Three of nine crush injuries caused two bruises, the remainder had single bruises; five of the nine crush injuries involved fingers or toes.

The presence or absence of petechial bruising and patterned bruising were explicitly recorded among the incidents recruited from ED. Among the 293 ED incidents, petechial bruising was observed just once, on the elbow of a girl who fell from a horse. Patterned bruising was observed in 9/293 (3.1\%) incidents, all involving children aged 4 years or more. Negative imprints (bruising around the point of impact) were seen over bony prominences in two incidents: one was over the anterior superior iliac spine of a boy who fell in the playground and the other was on the knee of a boy who was hit with a toy by his brother. A linear pattern was recorded in 5/559 (0.9\%) incidents. Two involved a fall from standing height hitting the edge of a door frame and back of a chair respectively, two impact injuries caused by running into the edge of a metal bench and the corner of a TV stand respectively and the fifth was due to a seat belt in a MVC. Clusters of more than one bruise per location were seen in only $2 / 141(1 \%)$ school-aged children, one playing football and the other from a fall of $1-2 \mathrm{~m}$. 
Table 3 The number and \% of bruises per mechanism of injury from 559 incidents where a bruise resulted from a known unintentional injury in children aged $<13$ years

\begin{tabular}{|c|c|c|c|c|c|c|c|c|c|}
\hline $\begin{array}{l}\text { Number of bruises } \\
\text { per injury incident }\end{array}$ & $\begin{array}{l}\text { All mechanisms } \\
\text { combined } \\
\text { (\% for all } \\
\text { mechanisms) }\end{array}$ & $\begin{array}{l}\text { Fall from }<1 \mathrm{~m} \\
\text { (\% for this } \\
\text { mechanism) }\end{array}$ & $\begin{array}{l}\text { Fall from standing } \\
\text { height or } \\
\text { less and hitting an } \\
\text { object } \\
\text { during fall } \\
\text { (\% for this mechanism) }\end{array}$ & $\begin{array}{l}\text { Fall from } 1 \text { to } \\
2 \mathrm{~m} \\
\text { (\% for this } \\
\text { mechanism) }\end{array}$ & $\begin{array}{l}\text { Stair fall } \\
\text { (\% for this } \\
\text { mechanism) }\end{array}$ & $\begin{array}{l}\text { Impact } \\
\text { injury } \\
\text { (\% for } \\
\text { this } \\
\text { mechani } \\
\quad \text { sm) }\end{array}$ & $\begin{array}{l}\text { Sports } \\
\text { injury } \\
\text { (\% for this } \\
\text { mechanism) }\end{array}$ & $\begin{array}{l}\text { Motor } \\
\text { vehicle } \\
\text { collision } \\
\text { (\% for this } \\
\text { mechanism) }\end{array}$ & $\begin{array}{l}\text { Crush injury } \\
\text { (\% for this } \\
\text { mechanism) }\end{array}$ \\
\hline 1 & $457 / 559(81.7)$ & $169 / 198(85.4)$ & $81 / 96(84.3)$ & $18 / 24(75.0)$ & $14 / 25(56.0)$ & $\begin{array}{l}136 / 142 \\
(95.8)\end{array}$ & $31 / 58$ (53.4) & $2 / 7(28.6)$ & $6 / 9(66.7)$ \\
\hline 2 & 77/559 (13.8) & 26/198 (13.1) & 11/96 (11.5) & $3 / 24(12.5)$ & $7 / 25(28.0)$ & $\begin{array}{l}6 / 142 \\
(4.2)\end{array}$ & $20 / 58$ (34.5) & $1 / 7(14.3)$ & 3/9 (33.3) \\
\hline$\geq 3$ & $25 / 559$ (4.5) & $3 / 198(1.5)$ & $4 / 96$ (4.2) & $3 / 24(12.5)$ & $4 / 25(16.0)$ & $\begin{array}{l}0 / 142 \\
(0.0)\end{array}$ & $7 / 58(12.1)$ & $4 / 7(57.1)$ & $0 / 9(0.0)$ \\
\hline
\end{tabular}


Further analysis, using a logistic regression model, showed that these findings do not enable the prediction of a mechanism from the age, gender, number and location of bruises, predominantly due to the very high number of mechanisms resulting in a single bruise.

\section{DISCUSSION}

This study records the distribution of bruising sustained from a variety of unintentional injuries in young children. We have shown that $457 / 559$ (81.7 \%) of injury incidents resulted in a single bruise, regardless of mechanism, the exception being MVCs. The most common sites of bruising for all mechanisms were the front of the body, below knees and forehead. Regardless of the mechanism, certain sites had no bruises in this dataset, namely ears, neck and genitalia, and petechiae were very rare.

The prevalence and number of bruises that a child has increases with increasing independent mobility. In this study, 476/559 (85.2\%) of bruises involved children who were walking independently, and only $7 / 559$ (1.3\%) incidents involved a non-mobile baby, not yet sitting. Overall, $414 / 559$ (74.1\%) of the bruise injuries did not present for medical attention, and represent the spectrum of those sustained by children from everyday incidents; this is particularly useful as many intentional injuries are ascribed to minor household incidents. The mechanism of injury changes with increasing age, for example, the peak incidence of slips and trips leading to craniofacial bruising is at toddler age, 5 while sports injuries occur predominantly in children aged 10-14 years, consistent with our data.

The common sites of unintentional bruising recorded were consistent with previous studies, although these studies have not described the mechanism of injuries. No bruising was observed on the ears, neck or genitalia, and rarely observed on buttocks, upper arm, back of the legs or feet, which are areas associated with abusive bruising. Previous studies have combined multiple body parts, for example, 'head and neck' which may fail to identify the rarity of bruising to specific body parts.

Multiple bruises following a single injury mechanism were rare, the exceptions included serious injuries such as MVC, or falls down $>10$ steps. Studies that have correlated the number of steps fallen with the severity of injury combined fractures, lacerations and bruising or did not detail bruising at all. A retrospective study of children with stair falls found that only $3 \%$ had an 'injury' to more than one body part, with no difference between falling 'a full flight of stairs' or 'less', although the number of steps fallen was not detailed.7 Previous studies have been retrospective chart reviews, with no information as to whether a 'top to toe' examination was conducted; thus, the true pattern of soft tissue injury may be incomplete. Limitations include the possibilities of participation and selection bias, and, an inability to define the incidence of bruising from specific mechanisms, as only children with a bruise were eligible for inclusion. As previously published, for the community cohort 622/1002 (62.1\%) who were approached refused, partly due to the longitudinal nature of data collection. Absolute numbers of refusals within the ED cohort were not documented, but were low overall. Kinematics of injury was not explored, for example, children who fell down stairs were grouped with those who were carried when a caregiver slipped. While exclusion of abuse cannot be absolute, the risk was minimised by voluntary participation, where the consent process explicitly 
stated that any cause for concern of abuse would require a child abuse assessment. These strenuous measures to minimise any risk of including abused children are in direct contrast to previous studies, where no mention of whether injuries were witnessed, or any child protection considerations, were given. Conversely, exclusion of incidents suspicious of abuse may have introduced bias by excluding some unintentional injuries. In our study, 132/293 (45.1\%) of patients seen in the ED were recruited within 6 hours of their injury; thus, some injuries may not have resulted in visible bruises within this time. Generalisability was improved by the recruitment of children from the community and ED setting, who were attending for reasons other than the injury causing the bruise.

\section{CONCLUSION}

This study provides a comprehensive description of the distribution of unintentional bruising that young children sustained from 559 incidents of common injury mechanisms. This novel dataset may aid clinicians in determining the plausibility of the history offered relative to the bruising seen, and highlights the rarity of certain features in unintentional bruises, including bruising to ears, neck or genitalia, multiple bruises from a single mechanism, or petechial bruising.

\section{REFERENCES}

1 Harper NS, Feldman KW, Sugar NF, et al. Additional injuries in young infants with concern for abuse and apparently isolated bruises. J Pediatr 2014;165:383-8.

2 Pierce MC, Bertocci BE, Janosky JE et al.Femur fractures resulting from Stair Falls among Children: an Injury Plausibility Model. Pediatrics 2005;115:1712-22.

3 Kemp AM, Maguire SA, Nuttall D, et al. Bruising in children who are assessed for suspected physical abuse. Arch Dis Child 2014;99:108-13.

4 Sheets LK, Leach ME, Koszewski IJ, et al. Sentinel injuries in infants evaluated for child physical abuse. Pediatrics 2013;131:701-7.

5 Chang LT, Tsai MC. Craniofacial injuries from slip, trip, and fall accidents of children.

J Trauma 2007;63:70-4.

6 Newman CJ, Holenweg-Gross C, Vuillerot C, et al. Recent skin injuries in children with motor disabilities. Arch Dis Child 2010;95:387-90.

7 Docherty $E$, Hassan A, Burke $D$. Things that go bump bump bump: an analysis of injuries from falling down stairs in children based at Sheffield Children's Hospital. Emerg Med J 2010;27:207-8.

8 Garzon DL, Lee RK, Homan SM. There's no place like home: a preliminary study of toddler unintentional injury. J Pediatr Nurs 2007;22:368-75.

9 Zielinski AE, Rochette LM, Smith GA. Stair-related injuries to young children treated in US emergency departments, 1999-2008. Pediatrics 2012;129:721-7. 
10 Dsouza R, Bertocci G. Impact sites representing potential bruising locations associated with rearward falls in children. Forensic Sci Int 2016;261:129-36.

11 Steele BD, Brennan PO. A prospective survey of patients with presumed accidental ear injury presenting to a paediatric accident and emergency department. Emerg Med J 2002;19:226-8.

12 Lutz N, Nance ML, Kallan MJ, et al. Incidence and clinical significance of abdominal wall bruising in restrained children involved in motor vehicle crashes. J Pediatr Surg 2004;39:972-5.

13 Kemp AM, Dunstan F, Nuttal D, et al. Patterns of bruising in preschool children - a longitudinal study. Arch Dis Child 2015;0:1-6.

14 ICECI Coordination and Maintenance Group. International Classification of External Causes of Injury (ICECI) version 1.2. Adelaide: Consumer Safety Institute, Amsterdam and AlHW National Injury Surveillance Unit, 2014. www. iceci. org (accessed 7 Jun 2016).

15 Welsh Government. Population Estimates by Ethnic Group. Statistics for Wales. 2011 http://gov.wales/statistics - and-research /population -estimates -ethnicity/ ?lang=en (accessed 7 Jun 2016).

16 Carpenter RF. The prevalence and distribution of bruising in babies. Arch Dis Child 1999;80:363-6.

17 Sugar NF, Taylor JA, Feldman KW. Bruises in Infants and Toddlers; Those who Don't Cruise Rarely Bruise. Arch Pediatr Adolesc Med 1999;153:399-403.

18 Unni P, Locklair MR, Morrow SE, et al. Age variability in pediatric injuries from falls.

Am J Emerg Med 2012;30:1457-60.

19 Conn JM, Annest JL, Bossarte RM, et al. Non-fatal sports and recreational violent injuries among children and teenagers, United States, 2001-2003. J Sci Med Sport 2006;9:479-89.

20 Petska HW, Sheets LK, Injuries S. Subtle findings of physical abuse. Pediatr Clin North Am 2014;61:923-35.

21 Sanders T, Cobley $\mathrm{C}$. Identifying non-accidental injury in children presenting to A\&e departments: an overview of the literature. Accid Emerg Nurs 2005;13:130-6.

22 Pierce MC, Kaczor K, Aldridge S, et al. Bruising characteristics discriminating physical child abuse from accidental trauma. Pediatrics 2010;125:67-74.

23 Joffe M, Ludwig S. Stairway injuries in children. Pediatrics 1988;82:457-61.

24 Mao SJ, McKenzie LB, Xiang $\mathrm{H}$, et al. Injuries associated with bathtubs and showers among children in the United States. Pediatrics 2009;124:541-7.

25 Pitone ML, Attia MW. Patterns of injury associated with routine childhood falls. Pediatr Emerg Care 2006;22:470-4. 
26 Chiaviello CT, Christoph RA, Bond GR. Stairway-related injuries in children. Pediatrics 1994;94:679-81.

27 Pennock AT, Gantsoudes GD, Forbes JL, et al. Stair falls: caregiver's "missed step" as a source of childhood fractures. J Child Orthop 2014;8:77-81.

28 Royal College of Emergency Medicine. Clinical Standards for Emergency Departments. 2014 www.rcem .ac uk/Shop - Floor/Clinical \% 20Standards (accessed 7 Jun 2016).

29 Royal College of Paediatrics and Child Health. Standards for children and young people in emergency care settings. 2012 www.rcpch. ac.uk /emergencycare (accessed 7 Jun 2016). 